\title{
DESIGN AND ANALYSIS OF A LOW COST SOLAR WATER PUMP FOR IRRIGATION IN BANGLADESH
}

\author{
Shahidul I. Khan ${ }^{1 *}$, Md. Mizanur R. Sarkar ${ }^{2}$ and Md. Quamrul Islam ${ }^{3}$ \\ ${ }^{1}$ Department of Electrical and Electronic Engineering \\ ${ }^{3}$ Department of Mechanical Engineering \\ Bangladesh University of Engineering and Technology (BUET), Dhaka 1000, Bangladesh \\ ${ }^{2}$ Power Grid Company of Bangladesh Ltd., Dhaka, Bangladesh \\ *Corresponding e-mail: shahidul@eee.buet.ac.bd
}

\begin{abstract}
Bangladesh, a developing country of south-east Asia with large population has agricultural economy. About 59 percent cultivable land needs irrigation. During dry season and due to climate change, demand of electricity for electric power irrigation is increasing. Irrigation by electric power is cheaper than diesel pump. Due to severe shortage of electricity it is difficult to meet the demand. Harnessing solar power for irrigation is a good alternative to grid electricity. This paper deals with the design, technical and economic analysis of a low cost $1 \mathrm{hp}(746 \mathrm{~W})$ small size dc photovoltaic water pumping system for irrigation. A buck converter is designed and constructed to improve the performance of the dc pump. All components of the system are procured locally except the solar panels.
\end{abstract}

Keywords: Solar water pump, irrigation, buck converter.

\section{INTRODUCTION}

During dry season in December-April, irrigation is necessary for rice and winter vegetable cultivation. There is severe energy crisis in Bangladesh. Only 53 percent population ${ }^{1}$ has access to electricity. Per capita power consumption is only $230 \mathrm{kWh}$. Most of the power supply is limited to urban areas; access to electricity in rural areas is less than $30 \%$. In Bangladesh three types of water pumps are used for irrigation, i.e. Low Lift Pump (LLP), Shallow Tube Well (STW) and Deep Tube Well (DTW). LLP and STW mostly use diesel and DTW is mainly operated by electricity. A solarpowered water pumping system initially costs more than a diesel or electric powered pump but requires far less maintenance and labor. Comparing installation costs (including labor), fuel costs and maintenance costs over 10 -year period, it is observed that solar pump is an alternate choice. Bangladesh situated between 20.30-26.38 ${ }^{\circ}$ north latitude and $88.04-92.44^{\circ}$ east longitude, with average solar radiation between 4 and 5 $\mathrm{kWh} / \mathrm{m}^{2} /$ day, is ideal location for solar energy harvesting.

With the reduction of price of solar panel and electronic components solar power is now an economically viable option for irrigation. A PV operated solar pump was tested for irrigation in Bangladesh Rice Research Institute (BARI) during 80 s. It was technically suitable for low lift small scale surface water irrigation. But this was not found economically viable at that time due to high cost of PV panels ${ }^{2}$. A Rutgers University study shows that vegetable growing using solar pump irrigation is cost effective compared to electricity powered drip irrigation ${ }^{3}$. Solar pump irrigation is also found economically viable by studies ${ }^{4,5,6}$. Solar pump may be an alternative for small scale irrigation for vegetable production in the off-grid areas especially in the char (small island) areas ${ }^{7}$ of Bangladesh. Solar powered pumping systems are capable of delivering water from rivers and wells in volumes up to $9000 \mathrm{l} /$ minute $^{3}$. A dc solar pump is designed and assembled ${ }^{8}$ using locally available components and tested in the Fluid Mechanics Laboratory of Mechanical Engineering Department of BUET. A pump controller using buck converter is designed and implemented to increase the overall efficiency of the pump. Its performance analysis and economic viability are also done and shown in this paper. The present $1 \mathrm{hp}(746 \mathrm{~W})$ solar pump is suitable for irrigation using surface water during winter season and during day time. Locally available pump and motor was never used before for solar water pumping in Bangladesh. The usefulness of this type of technology innovation is that farmers and technicians in remote villages can maintain and keep running this type of water pump system.

\section{DESIGN OF DC SOLAR PUMP}

A dc permanent magnet motor of $1 \mathrm{hp}(746 \mathrm{~W})$, $12 \mathrm{~V}$ was procured from local market and solidly coupled to the centrifugal pump. DC motor was chosen as it does not require an inverter. To see the performance, first the dc motor was connected directly to the solar panels. Twelve $75 \mathrm{~W}_{\mathrm{p}}, 12 \%$ efficient, solar modules were used as power source. About 450 watts of power could be obtained as the irradiance was only about 400 watts $/ \mathrm{m}^{2}$. To increase the current, modules were connected in combination of 5 panels in two rows and 2 panels in 1 row. The 
performance of the pump without any converter was not satisfactory as it could not supply the initial torque of the motor.

A buck converter is designed to supply initial high current to the motor for starting purpose and smooth running of the motor. The performance improved after the integration of buck converter. Buck converter reduces the panel voltage of 17-18 $\mathrm{V}$ (depending on sun shine) to $12 \mathrm{~V}$. Fig. 1 shows the design. The values of the components are, $\mathrm{V}_{\text {in }}=17 \mathrm{~V}, \mathrm{~V}_{\text {out }}=12 \mathrm{~V}$, Duty Cycle, $\mathrm{k}=0.705$, $\mathrm{I}_{\text {ripple }}=0.117 \mathrm{~A}, \quad \mathrm{~L}_{1}=1.004 \quad \mathrm{mH}, \quad \mathrm{C}_{\text {out }}=211 \mu \mathrm{F}$, $\mathrm{I}_{\text {diode }}=15.1689 \mathrm{~A}$.

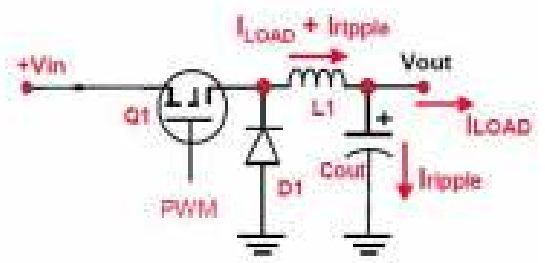

Figure 1. Buck converter for Power Conditioning Unit (PCU).

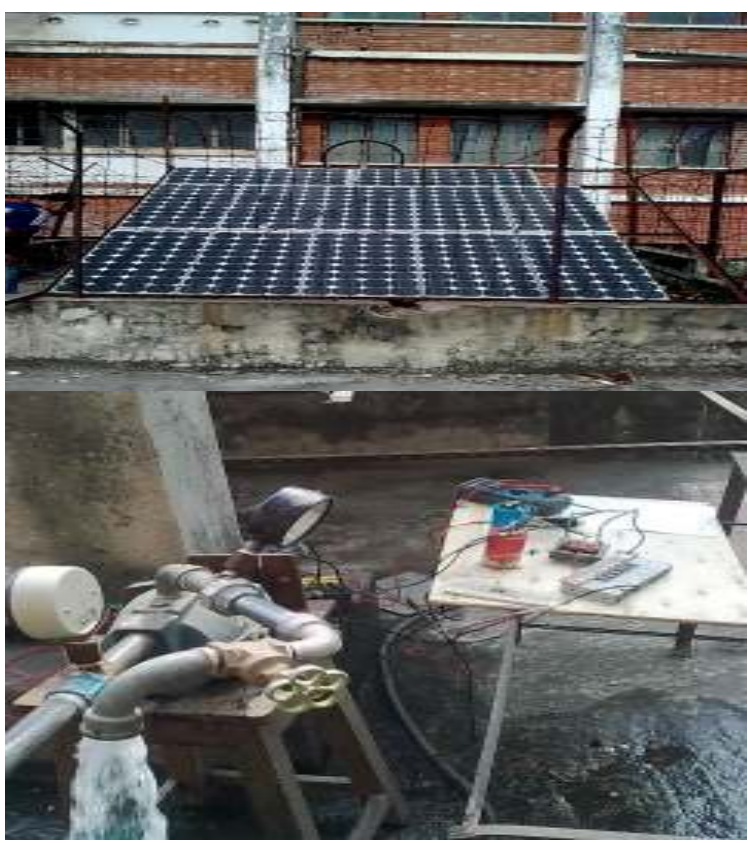

Figure 2. Top: The solar panels. Bottom: The experimental set-up on roof top near the panels.

\section{Data AnAlysis}

The solar panels were set-up at an angle of $23^{\circ}$ south facing (optimum angle for Bangladesh) on the roof top of adjacent laboratory. First the solar water pump was directly connected to the solar panel. It is found that the system works. However, as the dc motor works at $12 \mathrm{~V}$, a high current of 40 60 A would flow. Moreover, as the back emf of dc motor is related to the speed of the motor, it shows a lower speed than actually needed to run the pump. Final testing of the pump was done at the reservoir of Fluid Mechanics laboratory.

\section{No Load Test}

To check the performance of the pump after integration with the dc motor, no load test was performed. In the no load test, the system was supplied from de power supply in the laboratory without any load on the system. Supplied voltage, current and speed of the system were recorded as shown in Table 1.

Table 1. No load test data

\begin{tabular}{|c|c|c|}
\hline Voltage, $\mathbf{V}$ & Current, $\mathbf{A}$ & Speed, rpm \\
\hline 10 & 11.5 & 2400 \\
\hline 11 & 12.0 & 2560 \\
\hline 12 & 12.0 & 2850 \\
\hline 13 & 12.5 & 3060 \\
\hline 13 & 14.0 & 3200 \\
\hline
\end{tabular}

The highest no load speed goes up to 3000-3200 rpm. The result from the no load test reveals that the integration of the dc motor with the centrifugal pump matched satisfactorily.

\section{Direct Coupled System Performance}

The pump motor set was directly connected to the solar panels without any power conditioning unit. The voltage, current, speed and discharge are tabulated in Table 2. The performance is not satisfactory, because dc motor requires a high starting current which the panel could not supply. In absence of initial high current, voltage could not be built and the starting torque is low. So the water discharge was also low. Moreover, the alignment of the dc motor was not perfect with centrifugal pump, so the power transfer was less.

Table 2. Direct coupled system data

\begin{tabular}{|c|c|c|c|}
\hline Voltage, V & Current, A & $\begin{array}{c}\text { Speed, } \\
\text { rpm }\end{array}$ & $\begin{array}{c}\text { Discharge, } \\
\text { l/min }\end{array}$ \\
\hline 5 & 20 & 880 & 10 \\
\hline 5 & 22 & 920 & 13 \\
\hline 6 & 25 & 950 & 14 \\
\hline 6 & 28 & 1000 & 22 \\
\hline 6.1 & 30 & 1020 & 24 \\
\hline
\end{tabular}

System Performance using a Buck Converter

The designed buck converter is connected between motor-pump and solar panels. The performance improved. Data are collected over a period of few days in winter. The data are shown in 
Table III. The total head was considered as $18 \mathrm{ft}$ $(5.5 \mathrm{~m})$.

Table 3. Characteristics data of the solar pump

\begin{tabular}{|c|c|c|c|c|c|c|c|c|c|c|}
\hline 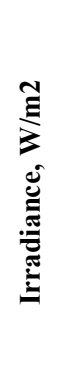 & 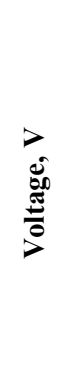 & 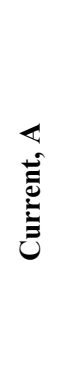 & 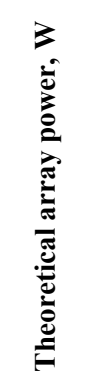 & 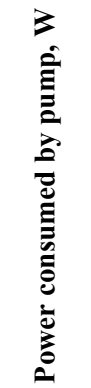 & 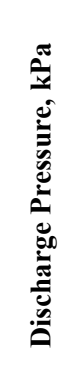 & 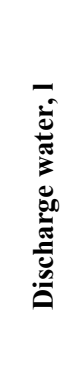 & 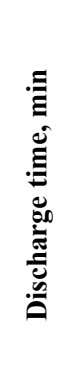 & 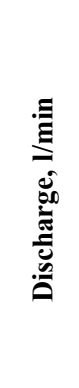 & 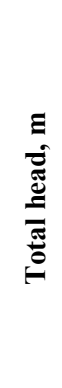 & 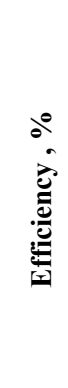 \\
\hline 278 & 5.30 & 25 & 253.16 & 132.50 & 48.27 & 7.90 & 1.12 & 7.03 & 5.40 & 4.60 \\
\hline 300 & 5.60 & 28 & 273.20 & 156.80 & 41.37 & 8.30 & 0.75 & 10.99 & 4.69 & 5.14 \\
\hline 330 & 6.10 & 31 & 300.52 & 189.10 & 34.48 & 13.82 & 0.66 & 20.99 & 4.08 & 7.50 \\
\hline 336 & 6.80 & 32 & 305.98 & 217.60 & 32.41 & 14.10 & 0.50 & 28.20 & 3.75 & 7.70 \\
\hline 345 & 7.00 & 35 & 314.18 & 245.00 & 28.96 & 6.50 & 0.17 & 38.23 & 3.44 & 8.80 \\
\hline 356 & 7.15 & 38 & 324.19 & 271.70 & 28.27 & 13.00 & 0.33 & 39.39 & 3.32 & 9.90 \\
\hline 365 & 7.36 & 42 & 332.40 & 309.10 & 27.58 & 9.70 & 0.17 & 58.20 & 3.26 & 10.10 \\
\hline
\end{tabular}

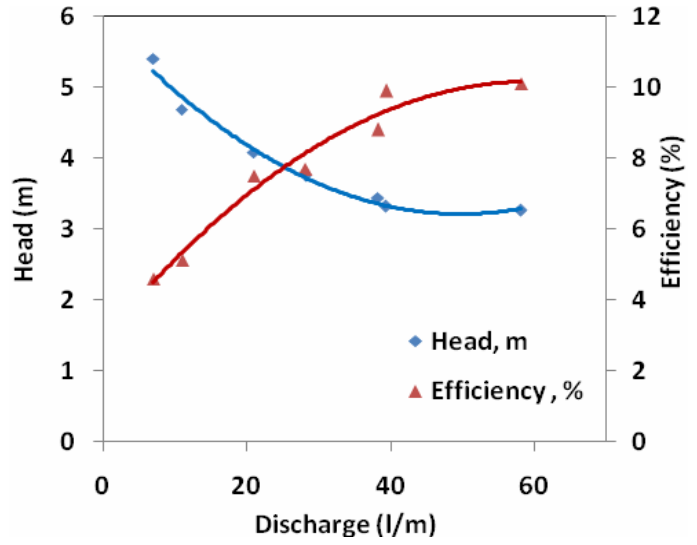

Figure 3. Discharge versus head and efficiency of the pump

The characteristic of solar pump motor is similar to theoretical characteristics. In Fig. 3, discharge increases as head decreases and efficiency increases as discharge increases. In Fig. 4, power consumed by pump is less than theoretical array power. The discharge capacity was found in the range of $35-58 \mathrm{1} / \mathrm{min}$. This discharge capacity is expected to increase in the summer season with increased irradiance.

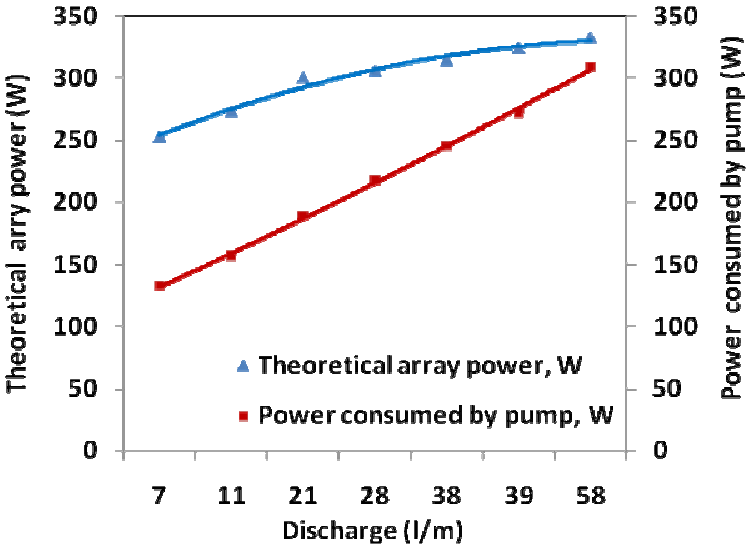

Figure 4. Discharge versus theoretical array power and power consumed by pump.

\section{PERFORMANCE AND COST ANALYSIS}

A de solar pump is designed and implemented using locally available technologies to investigate a way to reduce dependency on diesel and electricity driven water pumps in agriculture. The costs of these locally developed solar pumps will be less than the imported ones and repair, maintenance costs will also be low. Moreover, since these dc 
pumps will run without battery and inverter, maintenance will also be less and easy. This one horse $(746 \mathrm{~W})$ power solar pump system will cost about BDT.112,000. The BUET designed pump was compared with the results of a study of different typs of solar pump done at Bangladesh Agricultural Research Institute (BARI), Dhaka and is shown in Table 4.

Benefit cost ratio ${ }^{9}$ for solar irrigated tomato and brinjal (egg apple) by drip and furrow irrigation were $3.45,3.71$ and $1.57,1.37$ respectively. At present, rice cultivation by solar water pump is not economically viable.

\section{CONCLUSION}

Solar photovoltaic pumping offers a way out to the farmers of Bangladesh from the energy crisis. This paper demonstrates that solar photovoltaic technology can be integrated to irrigation systems in Bangladesh. Some technological challenges were overcome through engineering solutions and showed a representative model can be implemented. Upfront cost of the solar pumping systems potentially hinder to popularize the systems in rural areas but private companies, bank and government can come forward for a solution that can fit to rural people of Bangladesh. Advantages of the locally developed solar water pumping system are, cost of indigenous solar water pumping systems will less than imported ones, dependence on the demand of diesel and electricity will reduce, maintenance cost will be less because imported systems after passing of one year (guarantee) period take longer time and higher cost for repair. Moreover, due to use of local pump, local technicians and farmer can easily install and change the pumps whenever necessary. Higher panel efficiency and higher operating voltage will improve the performance of the pump. Carbon credit will be an added benefit.

Table 4. Comparisons of different types of solar pumps.

\begin{tabular}{|c|c|c|c|c|c|c|}
\hline Specification/features & $\begin{array}{l}\text { Designed by } \\
\text { BUET }\end{array}$ & $\begin{array}{l}\text { Designed by } \\
\text { BARI }\end{array}$ & $\begin{array}{l}\text { Designed by } \\
\text { Dhaka } \\
\text { University } \\
\text { (DU) }\end{array}$ & Made in USA & $\begin{array}{c}\text { Made in } \\
\text { Australia }\end{array}$ & Made in China \\
\hline Make and model & $\begin{array}{c}\text { BUET, } \\
\text { Bangladesh }\end{array}$ & $\begin{array}{c}\text { BARI, } \\
\text { Bangladesh }\end{array}$ & $\begin{array}{c}\text { DU, } \\
\text { Bangladesh }\end{array}$ & $\begin{array}{l}\text { Honeywell, } \\
\text { USA }\end{array}$ & $\begin{array}{l}\text { Mono Pumps, } \\
\text { Australia }\end{array}$ & $\begin{array}{l}\text { Lorentz, } \\
\text { Germany }\end{array}$ \\
\hline Pump type & Centrifugal & Centrifugal & Centrifugal & Centrifugal & Submersible & Submersible \\
\hline Motor type & dc & dc & ac & dc & dc & dc \\
\hline Suitability & Surface water & $\begin{array}{l}\text { Surface } \\
\text { water }\end{array}$ & Surface water & Surface water & $\begin{array}{c}\text { Surface and } \\
\text { ground water }\end{array}$ & $\begin{array}{c}\text { Surface and } \\
\text { ground water }\end{array}$ \\
\hline $\begin{array}{c}\text { Suction and delivery } \\
\text { pipe diameter, mm }\end{array}$ & $38\left(1.5^{\prime \prime}\right)$ & $38\left(1.5^{\prime \prime}\right)$ & $25\left(1.0^{\prime \prime}\right)$ & $38\left(1.5^{\prime \prime}\right)$ & $25\left(1.0^{\prime \prime}\right)$ & $38\left(1.5^{\prime \prime}\right)$ \\
\hline Motor capacity, W & 746 & 800 & 373 & 373 & 373 & 1640 \\
\hline Motor rpm (max.) & 3000 & 2800 & 2900 & 2800 & 3200 & 3200 \\
\hline Voltage, $\mathbf{V}$ & 12 & 48 & 220 & 58 & 180 & 90 \\
\hline $\begin{array}{c}\text { Total panel power, } \\
\text { W }\end{array}$ & 900 & 900 & 675 & 600 & 600 & 1050 \\
\hline $\begin{array}{c}\text { Average discharge, } \\
\text { 1/min }\end{array}$ & 56 & 60 & 34 & 100 & 90 & 120 \\
\hline $\begin{array}{c}\text { Price of pump set } \\
\text { with controller(BD } \\
\text { Taka) }\end{array}$ & 22000 & 25000 & 75000 & 150000 & 150000 & 200000 \\
\hline $\begin{array}{c}\text { Price of solar panels } \\
\text { (BDT) }\end{array}$ & 90000 & 90000 & 67500 & 60000 & 60000 & 105000 \\
\hline $\begin{array}{c}\text { Total cost of solar } \\
\text { pump, BDT* }\end{array}$ & 112,000 & 115,000 & 142,500 & 210,000 & 210,000 & 305,000 \\
\hline
\end{tabular}

*US\$ 1=BDT 83

\section{REFERENCES}

1. Upto-date Information of Power Sector, A Report by Power Cell, Ministry of Energy, Mineral Resources and Power, Government of Bangladesh, April, 2012.

2. M. A. Mazed, M. H. Rashid, M. M. Rahman, M. S. Islam and S. Borhan, 1987, "Performance evaluation of ARCO solar pump model CSB 50D in Bangladesh", Bangladesh Journal of Agricultural Engineering, Vol-1(1), pp. 17-20.

3. W. H. Tietjen, J. Grande, P. J. Nitzsche, T. Manning and E. Dager, 2008, "Solar pump drip irrigation for vegetable production", ASP proceedings, Rutgers CES of Warren County, 165 County Road 519 South, Belvidere, NJ 078231949.

4. K. R. Curtis, 2010, "Economic feasibility of solar photovoltaic irrigation system use in great basin forage production", Research Report, Department of Applied Economics, Utah State University.

5. N. C. Bhowmik, and others, 2009, "Development of solar water pumping using indigenous technology for irrigation", Research Report, Renewable Energy Research Centre, 
Energy park, University of Dhaka, Dhaka-1000, Bangladesh.

6. P. C. Pande, A. K. Singh, S. Ansari, S. K. Vyas and B. K. Dave, 2003, "Design, development and testing of a solar PV pump based drip system for orchards", Journal of Renewable Energy, Vol.28(3), pp. 385-396.

7. M. A. Hossain, M. S. Hassan, M. A. R. Sarkar and B. K. Bala, 2003, "Solar energy in agriculture in Bangladesh", Proceedings of the 3rd Int. Conference on Renewable Energy for Sustainable Development (ICRESD 2003), Dhaka, Bangladesh, pp. 537-546.
8. Md. Mizanur Rahman Sarkar, 2011, "Design of an Efficient Photovoltaic Pump for Irrigation", M.Sc. Engineering Thesis, EEE Dept., BUET, Bangladesh.

9. M. A. Hossain, M. S. Islam, M. S. Hassan and M. A. Mottalib, 2012, "Techno-economic study of small-scale solar pump for irrigation', Proceedings National Seminar on Renewable Energy, Institute of Renewable Energy, Dhaka University, Bangladesh Solar Energy Society, Dhaka. 